\author{
Paulina Krukowska-Siembida \\ Maria Curie-Skłodowska University in Lublin \\ ORCID: 0000-0002-1266-4862 \\ paulina.krukowska@umcs.pl
}

\title{
Independence of the Judges of the European Court of Human Rights
}

\author{
Niezależność sędziów Europejskiego Trybunału Praw Człowieka
}

\author{
SUMMARY
}

The authority and credibility of the European Court of Human Rights depend on the independence of its judges. The aim of this article is to present the analysis of the criteria of office, the electoral procedure, the terms of office, as well as privileges and immunities of the ECtHR judges.

Keywords: European Court of Human Rights; judge; independence; electoral procedure

\section{INTRODUCTION}

Judicial independence and impartiality are important factors which are to guarantee a high level of credibility and authenticity of international courts and tribunals. This subject has been thoroughly discussed in the literature ${ }^{1}$ and now almost all statutes and rules of procedure of international courts and tribunals contain the requirement of judicial independence, including Article 2 of the Statute of the International Court of Justice ${ }^{2}$, and Article 2 of the Statute of the International Tribunal

1 See e.g. J.I. Charney, The Impact on the International Legal System of the Growth of International Courts and Tribunals, "New York University Journal of International Law and Politics" 1999, Vol. 31(4), pp. 697-708; C.P.R. Romano, The Proliferation of International Judicial Bodies: The Pieces of the Puzzle, "New York University Journal of International Law and Politics" 1999, Vol. 31(4), pp. 833-842; C. Brown, Evolution and Application of Rules Concerning Independence of the International Judiciary, "The Law and Practice of International Courts and Tribunals" 2003, Vol. 2(1), DOI: https://doi.org/10.1163/157180303100420195, pp. 63-96.

2 Statute of the International Court of Justice, 26 June 1945, 59 Stat. 1055, 33 U.N.T.S. 933. 
for the Law of the $\mathrm{Sea}^{3}$. The established scholarly opinion stresses that the status of judges, besides institutional conditions (manner of authorisation) and budgetary aspects, directly affects the independence of a given court ${ }^{4}$.

This article is intended to be an attempt to analyse the legal status of the judges of the European Court of Human Rights (ECtHR), considered by most scholars of international law the most prominent contemporary body for international protection of human rights.

\section{PROCEDURE FOR PROPOSING CANDIDATES FOR JUDGES}

The European Court of Human Rights has repeatedly indicated which elements should be taken into account in determining the compliance with the conditions of independence of the court, including the manner of appointing the judges, the duration of their term of office, the appropriate financial status of the judges, the rules of disciplinary responsibility of the judges, the procedure for suspending or removing the judges from office and the existence of bulwarks against external pressure, and the question of whether the court displays independence 5 . Article 20 of the Convention for the Protection of Human Rights and Fundamental Freedoms ${ }^{6}$ contains two principles defining the composition of the Court: qualitative one - the Court is to consist of "judges", and quantitative on - the number of judges is equal to that of the High Contracting Parties ${ }^{7}$. This is an expression of the principle of equality of the Member States, because each Member State, regardless of size, political and economic position, has the right to appoint one judge at the ECtHR.

3 Statute of the International Tribunal for the Law of the Sea (Annex VI of the United Nations Convention on the Law of the Sea).

4 P. Sands, Global Governance and the International Judiciary: Choosing Our Judges, "Contemporary Legal Problems" 2003, Vol. 56(1), DOI: https://doi.org/10.1093/clp/56.1.481, p. 502: "If we are happy to have international courts fulfil political functions that tie them closely to international organizations, then perhaps we should not get too exercised about how judges are appointed. If, however, we see international courts and tribunals as exercising judicial functions analogous to those we expect of our national courts, then it is right to focus our attention on who the judges are and how they attain their offices".

5 D. Zawistowski, Niezależność sądów i niezawistość sędziów z perspektywy prawa Unii Europejskiej, „Ruch Prawniczy i Ekonomiczny” 2016, nr 2, DOI: https://doi.org/10.14746/rpeis.2016.78.2.2, p. 12. See judgement of the European Court of Human Rights of 25 February 1997 in the case Findlay v. the United Kingdom.

6 Convention for the Protection of Human Rights and Fundamental Freedoms, Rome, ETS No. 005 (version prior to the entry into force of Protocol No. 11), hereinafter referred to as the Convention or ECHR; Protocol No. 14 to the Convention for the Protection of Human Rights and Fundamental Freedoms, amending the control system of the Convention, CETS No. 194.

7 L. Garlicki, Konwencja o ochronie praw człowieka i podstawowych wolności, t. 2: Komentarz do artykułów 19-59 oraz Protokołów dodatkowych, Warszawa 2011, p. 25. 
It is worth noting here that the principle of quantitative equality of judges and Member States is also adopted at the Court of Justice in the European Union, but it is not applicable in other regional courts of human rights or other international courts $^{8}$. Therefore, while the judges sit in the ECtHR on their own behalf, the High Contracting Parties propose their candidates for the judges.

The manner of proposing candidates for international judges is a preliminary, but important, instrument for ensuring the independence of judges ${ }^{9}$. When analysing the requirements prescribed for candidates for the judges of the European Court of Human Rights, it should be pointed out that they are of a Convention-based and non-Convention nature. In accordance with the provisions of Article 21 paragraph 1 of the Convention "the judges shall be of high moral character and must either possess the qualifications required for appointment to high judicial office or be jurisconsults of recognised competence". These criteria have a very general and vague nature. The literature predominantly shares the view that the phrase "of high moral character" should be perceived as the condition of "impeccable character" in the Polish law on common courts ${ }^{10}$. This condition means high moral qualifications, a strong personality, a great sense of responsibility and wide intellectual horizons ${ }^{11}$. A certain interpretation directive for the requirement of "high moral character" may be the Resolution on Judicial Ethics adopted by the Plenary Court on 23 June 2008, according to which the judges should:

- act in line with the high moral character and act so as to uphold the standing and reputation of the Court,

- perform their duties diligently, maintain a high level of competence and strive to develop their professional skills on a continuous basis,

- exercise the utmost discretion in relation to secret or confidential information relating to proceedings before the Court,

- exercise their freedom of expression in a manner compatible with the dignity of their office,

- not accept any gift, favor or advantage that could call their independence or impartiality into question.

The requirements regarding the professional status and professional qualifications of the judges have been provided for in an alternative manner: one of these requirements is having the qualifications required for appointment to "high judicial office" while another is having the status of a "jurisconsult of recognised

\footnotetext{
8 Ibidem, p. 26.

9 J. Kolasa, Niezależność sędziego międzynarodowego. Zarys problemu, [w:] Współczesne sądownictwo międzynarodowe, red. J. Kolasa, t. 2, Wrocław 2010, p. 16.

${ }^{10}$ See e.g. L. Garlicki, op. cit.; M. Romańska, Pozainstancyjne środki ochrony prawnej, Warszawa 2013.

${ }_{11}$ T. Ereciński, J. Gudowski, J. Iwulski, Prawo o ustroju sądów powszechnych. Ustawa o KRS. Komentarz, Warszawa 2009, p. 211.
} 
competence"12. L. Garlicki argues that a liberal formula was adopted ${ }^{13}$. In practice, this may result in the appointment as ECtHR judges those who have just started their professional career.

The provisions of Article 21 paragraph 1 ECHR set out treaty criteria for office for the judges, but the Parliamentary Assembly of the Council of Europe has several times "supplemented" these criteria in its resolutions. The Guidelines of the Committee of Ministers on the selection of candidates for the post of judge at the European Court of Human Rights have provided for that candidates must, as an absolute minimum, be proficient in one official language of the Council of Europe (English or French) and should also possess at least a passive knowledge of the other, so as to be able to play a full part in the work of the Court (item II.3 of the Guidelines) ${ }^{14}$. This is necessary in order to make a useful contribution to the Court's work, given that the Court uses only those two languages ${ }^{15}$. Another important issue is the diversification of candidates for judges in terms of sex ${ }^{16}$. This was the subject of numerous discussions and debates, and even the first advisory opinion issued by the ECtHR because the Committee of Ministers asked whether a list of candidates for the post of ECtHR judge, which meets the criteria formulated in Article 21 of the Convention may be rejected only based on sex-related issues ${ }^{17}$. ECtHR assumed that the High Contracting Parties had set limits that could not be exceeded by the Assembly by actions aimed at ensuring the representation of the

${ }_{12}$ M. Balcerzak, Niezależność Europejskiego Trybunału Praw Człowieka a status jego sędziów, „Problemy Współczesnego Prawa Międzynarodowego Europejskiego i Porównawczego” 2014, t. 12, p. 41.

${ }_{13}$ L. Garlicki, op. cit., p. 31.

14 A. Przyborowska-Klimczak, Sędziowie trybunałów międzynarodowych - kryteria i zasady wyboru, [in:] Pro Scientia Iuridica, red. M. Chrzanowski, A. Przyborowska-Klimczak, P. Sendecki, Lublin 2014, p. 305. The official languages of the ECtHR are English and French. See Resolution of the Parliamentary Assembly No. 1646 (2009) of 27 January 2009. See also Guidelines of the Committee of Ministers on the selection of candidates for the post of judge at the European Court of Human Rights, CM(2012)40. The Guidelines of the Committee of Ministers contain the following suggestions: candidates need to have knowledge of the national legal system(s) and of public international law. Practical legal experience is also desirable; lists of candidates should as a general rule contain at least one candidate of each sex, unless the sex of the candidates on the list is under-represented on the Court (under $40 \%$ of judges) or if exceptional circumstances exist to derogate from this rule.

15 See the ECtHR Advisory Opinion of 12 February 2008, $\S 47$.

16 See e.g. J. Linehan, Women and Public International Litigation. Background Paper, prepared for a seminar held by the Project on International Courts and Tribunals and Matrix Chambers, London, 13 July 2001; R. Mackenzie, P. Sands, International Courts and Tribunals and the Independence of the International Judge, "Harvard International Law Journal" 2003, Vol. 44(1), p. $282 \mathrm{ff}$.

17 When negotiating the Protocol 14, an idea was proposed to introduce into Article 22 ECHR the requirement for countries to submit lists both for male and female candidates. This was the subject of a dispute with the Government of Malta, whose list of candidates for judges was rejected just because of the presentation of male candidates only. 
under-represented sex on the lists of candidates. These limits come down to the restriction that such actions cannot result in hindering the Member States from proposing candidates that meet all the criteria under Article 21 paragraph 1 ECHR, which should be given priority ${ }^{18}$.

\section{GUARANTEE OF INDEPENDENCE AND IMPARTIALITY OF JUDGES}

According to J. Kolasa, the selection of candidates for judges is of fundamental importance in the procedure of elections of independent international judges, because even the most elaborated electoral system is not able to fulfil its task satisfactorily if the group of candidates is not properly preselected ${ }^{19}$. Within the meaning of the ECHR, judges should sit on the Court in their individual capacity (Article 21 paragraph 2 ECHR), and during their term of office the judges must not engage in any activity which is incompatible with their independence, impartiality or with the demands of a full-time office (Article 21 paragraph 3 ECHR). The Plenary Court on judicial ethics issued on 23 June 2008 a resolution, in which it provided for that: "In the exercise of their judicial functions, judges shall be independent of all external authority or influence. They shall refrain from any activity or membership of an association, and avoid any situation, that may affect confidence in their independence". According to L. Garlicki, the judge, in the exercise of his office, may be guided only by his conscience and knowledge, applying, according to them, the provisions of the Convention and established case-law ${ }^{20}$. The judge may not engage in any additional activity except insofar as this is compatible with independence, impartiality and the demands of their full-time office. This requirement was the subject of amendments introduced by Protocol 11. From now on, the ECtHR judges may not undertake any actions that would prevent the full-time function of the judge ${ }^{21}$. Judges confirm their independence when taking oath or making solemn declaration: "I swear" or "I solemnly declare that I will exercise my functions as a judge honourably, independently and impartially and that I will keep secret all deliberations" ${ }^{\prime 22}$.

The diplomatic privileges and immunities granted to them protect judicial independence. They are very general in nature and in many cases even identical to those vested in representatives of States or international organizations ${ }^{23}$. Pursu-

${ }^{18}$ For more, see M. Kowalski, Pierwsza opinia doradcza Europejskiego Trybunału Praw Człowieka, „Europejski Przegląd Sądowy” 2018, nr 7, pp. 49-55.

19 J. Kolasa, op. cit., p. 18.

${ }^{20}$ L. Garlicki, op. cit., p. 34. See also R. Mackenzie, P. Sands, op. cit., p. 282 ff.

${ }^{21}$ In the literature, this is referred to as an abandonment of the idea of "commuting judges".

${ }^{22}$ See Rule 3 item 1 of the Rules of Court.

23 J. Kolasa, op. cit., p. 41. 
ant to Article 51 ECHR "The judges shall be entitled, during the exercise of their functions, to the privileges and immunities provided for in Article 40 of the Statute of the Council of Europe and in the agreements made thereunder". Article 51 does not automatically guarantee any privileges and immunities, it refers in this respect to Article 40 of the Statute of the Council of Europe, which states as follows:

a. The Council of Europe, representatives of Members and the Secretariat shall enjoy in the territories of its Members such privileges and immunities as are reasonably necessary for the fulfilment of their functions. These immunities shall include immunity for all Representatives to the Consultative (Parliamentary) Assembly from arrest and all legal proceedings in the territories of all Members, in respect of words spoken and votes cast in the debates of the Assembly or its committees or commissions.

b. The Members undertake as soon as possible to enter into agreement for the purpose of fulfilling the provisions of paragraph a. above. For this purpose the Committee of Ministers shall recommend to the Governments of Members the acceptance of an Agreement defining the privileges and immunities to be granted in the territories of all Members. In addition, a special Agreement shall be concluded with the Government of the French Republic defining the privileges and immunities which the Council shall enjoy at its seat ${ }^{24}$.

Among executive agreements concluded under Article 40 of the Statute of the Council of Europe, the most important is Sixth Protocol to the General Agreement on Privileges and Immunities of the Council of Europe ${ }^{25}$, pursuant to which, in addition to the privileges and immunities specified in Article 18 of the General Agreement, judges shall be accorded in respect of themselves, their spouses and minor children the privileges and immunities, exemptions and facilities accorded to diplomatic envoys in accordance with international law ${ }^{26}$. Immunity protection is granted to the judges commencing from the date of election for the position by the Parliamentary Assembly of the Council of Europe, that is in fact before the official assumption of the position, and is terminated when the office is vacated. In addition, Article 3 of Protocol No. 6 grants to judges the immunity from legal

${ }^{24}$ Statute of the Council of Europe, ETS No. 001.

${ }^{25}$ European Treaty Series No. 162.

${ }^{26}$ Cf. J. Kolasa, op. cit., p. 42 ff. According to Kolasa, although judges of international courts take advantage of privileges and immunities equivalent to those granted to representatives of States, in fact, their legal situation is different. Representatives of States act according to the instructions of their respective States, on their behalf and in their interest. However, judges of international courts do not represent individual States, they operate regardless of their country. Their privileges and immunities are not vested in their countries or to them in their own interest but in the interest of the whole court as such, whose purpose is to resolve disputes, which essentially is based on the interpretation and application of the law. 
process in respect of words spoken or written and all acts done by them in discharging their duties. In relation to the duration of exercising the function, this is only a clarification of the general immunity, and - in addition - the immunity provided for in Article 3 has been given a continuous form, so it remains effective even after the termination of the judge's term ${ }^{27}$. Therefore, it can be assumed that the ECtHR judges have "full-fledged" privileges and immunities accorded for the highest-class heads of mission within the meaning of Article 1a in conjunction with Article 14 paragraph 1a of the Vienna Convention on diplomatic relations, i.e. heads of mission in the rank of ambassador or equivalent $\mathrm{t}^{28}$.

Article 18 of the General Agreement grants judges a number of privileges, including inviolability of personal baggage, all papers and documents, the right to particularly protected forms of receiving and sending correspondence, the right to enter and reside freely in the country where the office is exercised, and in other countries visited as part of their functions or during transit, the right to tax exemptions (regarding salary and emoluments paid by the Council of Europe).

\section{JUDGE ELECTION PROCEDURE}

According to the wording of Article 22 ECHR, the judges are elected by the Parliamentary Assembly with respect to each High Contracting Party, from a list of three candidates nominated by the High Contracting Party. There are three basic principles for filling the posts of judges of the Court:

- the "national" composition of the Court: each Member State itself participates in the process of selecting a judge who sits on its behalf in the Court,

- the "European" right of decision: the election of a judge is carried out by the Parliamentary Assembly,

- the real character of the election: the role of the Assembly now goes beyond simply accepting or rejecting the preferred candidate by the proposing State ${ }^{29}$.

A characteristic feature of the judge election procedure is the division of competences between a State-party to the Convention and the Parliamentary Assembly ${ }^{30}$. The State's role is to provide the list of candidates meeting the criteria provided for in Article 21 ECHR. Within this framework, as established by the Convention, States are free to specify their lists of candidates ${ }^{31}$. In practice, however, there were

\footnotetext{
27 L. Garlicki, op. cit., p. 427.

28 M. Balcerzak, op. cit., p. 52.

29 L. Garlicki, op. cit., p. 37.

30 M. Balcerzak, op. cit., p. 44.

31 See the ECtHR Advisory Opinion of 22 January 2010, $\S 45$.
} 
situations when Member States took advantage of their position by presenting lists of candidates to guarantee the selection of their protegee. There were also cases of proposing candidates who were obviously not independent from governments for example, active ambassadors - and accompanied by pressure to accept them ${ }^{32}$. Therefore, the principle was adopted that candidates for judges nominated by the States will be verified at the level of bodies of the Council of Europe ${ }^{33}$. The Parliamentary Assembly of the Council of Europe, in Resolution 1646 of 27 January 2009 formulated standards, according to which the Member States should carry out the selection of their candidates ${ }^{34}$. Especially noteworthy is the requirement to issue public and open calls for candidatures, transmit the names of candidates to the Assembly in alphabetical order along with information on how to make the nomination and attached CVs of candidates according to the standardised curriculum vitae form. Additional guidance has been formulated by the Steering Committee for Human Rights. Apart from repeating the criteria contained in Article 21 ECHR, it requires that candidates for judges must have knowledge of the national legal system and public international law, practical legal experience being also desirable. In addition, if elected, candidates should, in general, be able to hold office for at least half of the nine-year term before reaching 70 years of age, and the election of the candidate should not lead to the frequent and long-lasting need to appoint ad hoc judges ${ }^{35}$.

A new element in the procedure for nominating candidates for judges - for lists compiled after 10 November 2010 - is the obligation for the contracting party to obtain an opinion from the Advisory Panel of Experts on Candidates for Election as Judge to the European Court of Human Rights, established by the Resolution of the Committee of Ministers CM/Res(2010)26 of 10 November $2010^{36}$. It has an advisory nature involving issuing an assessment whether the candidates nominated by the State meet the requirements provided for in Article 21 ECHR. If the Panel finds that one or more candidates for a judge do not meet the criteria required by the Convention, a written two-step panel response procedure has been provided for: informing the Member State by the Chair of the Panel about the fact of obtaining a commentary and - if the State's position does not modify the assessment

${ }^{32}$ J. Kolasa, op. cit., p. 23.

33 Ibidem, p. 40: "[...] a system of the »hearing « of candidates by the subcommittee (especially appointed for this purpose by the Committee on Legal Affairs and Human Rights of PACE) was adopted, and a standard CV form for candidates was established, which provides more information about their qualifications and experience".

${ }^{34}$ Resolution of the Parliamentary Assembly 1646 (2009) of 27 January 2009.

35 See Guidelines of the Committee of Ministers on the selection of candidates for the post of judge at the European Court of Human Rights, CM(2012)40, adopted by the Committee of Ministers on 28 March 2012.

${ }^{36}$ M. Balcerzak, op. cit., p. 45. 
of the candidate, the communication of the Panel's opinion to the Member State in a confidential manner ${ }^{37}$. The Panel's role is therefore solely advisory, and undoubtedly the weakness of this solution is the fact that neither Member States nor the Parliamentary Assembly are formally bound by the opinion communicated by the Panel of Experts ${ }^{38}$.

The lists of candidates are then forwarded to the Parliamentary Assembly within the time limit set by the Secretary General of the Council of Europe. The moment of submitting the list, however, marks an end of State's exercise of its decision-making power, since at this moment the decisions are moved to the level of the Parliamentary Assembly ${ }^{39}$. This is important because from now on the State can neither withdraw nor modify the list of candidates submitted ${ }^{40}$.

The next stage is the assessment in terms of substantive professional background, language skills and balance between sexes by the Subcommittee on the selection of judges of the ECtHR, composed of individual political groups of the Assembly on a representation basis. The Subcommittee may give positive opinion on the lists of candidates or propose that the PACE Bureau return the list to the State in order to draw up it again. Where accepted - all three candidates are subject to a secret ballot voting within the Assembly. An absolute majority of votes is required to be elected. If none of the candidates is given the required majority, then a second ballot is held in which the candidate who has received the simple majority votes wins. According to Article 3 of the Rules of Court, each elected judge assumes the office having taken an oath (or having made a solemn declaration) before the President of the Court and in presence of Court's judges.

The judges are elected for a period of 9 years. They may not be re-elected (Article 23 paragraph $1 \mathrm{ECHR})^{41}$. The terms of office of judges expire when they reach

37 Ibidem.

${ }^{38}$ In 2012, despite the negative opinion of the Expert Panel, A. Pejchal (from the Czech Republic) was elected judge of the Court.

${ }^{39}$ L. Garlicki, op. cit., p. 46.

40 This issue was the subject of a dispute between the Ukrainian government and PACE, which caused the issue of the advisory opinion by the ECHR on 22 January 2010. The Court invoked three general principles as the basis for resolving the issues presented in the Committee of Ministers' request: the principle of effective protection of human rights as a goal of the ECHR, the need to ensure the authority and proper functioning of the ECtHR, including the interpretation of Articles 21 and 22 ECHR in a manner that best serves the independence and impartiality of the Court and its judges, and the principle of balance and division of powers between Member States and the Parliamentary Assembly pursuant to Article 22 of the Convention. For more, see Advisory opinion on certain legal questions concerning the lists of candidates submitted with a view to the election of judges to the European Court of Human Rights No. 2, Strasbourg, 22 January 2010.

${ }^{41}$ See L. Garlicki, op. cit., p. $50 \mathrm{ff} .:$ "The formulation of the principle of rotation in office has undergone a significant evolution since the Convention became effective. Initially, the 9-year term of office was adopted and the re-election of the judge in office was allowed (Article 40 paragraph 1). Protocol No. 11 reduced the term of office to 6 years (which was associated with the transformation of 
the age of 70, but the expiration of the term of office or the completion of the age of 70 does not automatically dismiss the office-holder. The Convention, in Article 23 paragraph 3 provides for two exceptions in this respect: the judges hold office until replaced and, second, they continue to deal with such cases as they already have under consideration. In practice, it is recognised that the former judge participates in the settlement of all cases in which the hearing has already taken place (this applies in particular to proceedings before the Grand Chamber), as well as cases in which, due to the particular sensitivity or divergence of preliminary opinions of the judges, such participation is necessary ${ }^{42}$. The judge's mandate expires in the event of resignation or in the event of dismissal from the position held. The dismissal may only take place if the judge has ceased to meet the requirements (Article 23 paragraph 4 ECHR). An exclusive decision regarding the dismissal of the judge is reserved to the Court acting as the Plenary Court; it is obvious that the principle of independence excludes the participation of both the State which proposed the judge for the Court and the participation of other bodies of the Council of Europe ${ }^{43}$. These are the only possibilities of expiry of the mandate of a judge against his will.

Protocol No. 15 to the ECHR ${ }^{44}$ introduced further changes concerning the age of ECtHR judges. Its entry into force - after ratification by all Member States Parties - will abolish the provision on the expiration of the judge's term upon the age of 70, but at the same time will introduce the age limit for candidates for judges: 65 years on the day the Parliamentary Assembly requests the Member State for the presentation of a list of three candidates, in accordance with Article 22 of the Convention ${ }^{45}$. Candidates for international judicial bodies are usually people having extensive professional experience, usually middle-aged, but sometimes persons under 30 years of age have been proposed as candidates to the European Court of Human Rights ${ }^{46}$.

the Court into a standing judicial body) but allowing some exceptions (Article 23 paragraphs 3 and 4) while keeping the possibility of re-election (Article 23 paragraph 1). Protocol No. 14 again adopted a uniform 9-year term, but - which was a fundamental change - ruled out the option of re-election".

${ }^{42}$ Ibidem, p. 54.

${ }^{43}$ Ibidem, p. 54.

${ }^{44}$ Protocol No. 15 amending the Convention for the Protection of Human Rights and Fundamental Freedoms, CETS No. 213, Strasbourg, 24 June 2013, www.echr.coe.int/Documents/Protocol_15_ENG.pdf, Article 2. Opened for signature on 16 May 2013. As of 15 August 2018, the Protocol was ratified by 43 Member States.

${ }^{45}$ M. Balcerzak, op. cit., p. 48.

${ }^{46}$ A. Przyborowska-Klimczak, op. cit., p. 308. 


\section{CONCLUSION}

Due to their role, international judges face serious professional challenges, as they come from different regions of the world and various legal systems, have different professional background, as well as different individual traits of personality and character ${ }^{47}$. The credibility and legitimacy of the European Court of Human Rights depend on the independence and impartiality of judges deciding cases therein. No formal requirements per se will guarantee independence of the judges. The procedures for electing candidates for judges at both the national and the Council of Europe levels should be clear and transparent because it is the choice of the right people that will determine the authority of the Court itself.

In order to improve the mechanisms for the election of judges for the ECtHR, it may be proposed, for the law as it should stand, to increase the prominence of the Panel of Experts so that its assessment would have a real impact, through its binding nature, on the list of candidates for judges prepared by Member States. Transparency is a paramount and priority value, so the process of nominating candidates for judges should be fully public in order to minimize the risk of choosing a judge with insufficient qualifications or of dubious impartiality.

\section{REFERENCES}

Advisory opinion on certain legal questions concerning the lists of candidates submitted with a view to the election of judges to the European Court of Human Rights No. 2, Strasbourg, 22 January 2010.

Balcerzak M., Niezależność Europejskiego Trybunału Praw Człowieka a status jego sędziów, „Problemy Współczesnego Prawa Międzynarodowego Europejskiego i Porównawczego" 2014, t. 12.

Brown C., Evolution and Application of Rules Concerning Independence of the International Judicia$r y$, "The Law and Practice of International Courts and Tribunals" 2003, Vol. 2(1), DOI: https:// doi.org/10.1163/157180303100420195.

Charney J.I., The Impact on the International Legal System of the Growth of International Courts and Tribunals, "New York University Journal of International Law and Politics" 1999, Vol. 31(4).

Convention for the Protection of Human Rights and Fundamental Freedoms, Rome, ETS No. 005 (version prior to the entry into force of Protocol No. 11).

ECtHR Advisory Opinion of 12 February 2008.

ECtHR Advisory Opinion of 22 January 2010.

Ereciński T., Gudowski J., Iwulski J., Prawo o ustroju sądów powszechnych. Ustawa o KRS. Komentarz, Warszawa 2009.

Garlicki L., Konwencja o ochronie praw człowieka i podstawowych wolności, t. 2: Komentarz do artykułów 19-59 oraz Protokołów dodatkowych, Warszawa 2011.

Guidelines of the Committee of Ministers on the selection of candidates for the post of judge at the European Court of Human Rights, CM(2012)40.

47 Ibidem, p. 309. 
Judgement of the European Court of Human Rights of 25 February 1997 in the case Findlay v. the United Kingdom.

Kolasa J., Niezależność sędziego międzynarodowego. Zarys problemu, [w:] Wspótczesne sądownictwo międzynarodowe, red. J. Kolasa, t. 2, Wrocław 2010.

Kowalski M., Pierwsza opinia doradcza Europejskiego Trybunału Praw Człowieka, „Europejski Przegląd Sądowy" 2018, nr 7.

Linehan J., Women and Public International Litigation. Background Paper, prepared for a seminar held by the Project on International Courts and Tribunals and Matrix Chambers, London, 13 July 2001.

Mackenzie R., Sands P., International Courts and Tribunals and the Independence of the International Judge, "Harvard International Law Journal" 2003, Vol. 44(1).

Protocol No. 14 to the Convention for the Protection of Human Rights and Fundamental Freedoms, amending the control system of the Convention, CETS No. 194.

Protocol No. 15 amending the Convention for the Protection of Human Rights and Fundamental Freedoms, CETS No. 213, Strasbourg, 24 June 2013, www.echr.coe.int/Documents/Protocol_15_ENG.pdf.

Przyborowska-Klimczak A., Sędziowie trybunatów międzynarodowych - kryteria i zasady wyboru, [in:] Pro Scientia Iuridica, red. M. Chrzanowski, A. Przyborowska-Klimczak, P. Sendecki, Lublin 2014.

Resolution of the Parliamentary Assembly No. 1646 (2009) of 27 January 2009.

Romano C.P.R., The Proliferation of International Judicial Bodies: The Pieces of the Puzzle, "New York University Journal of International Law and Politics" 1999, Vol. 31(4).

Romańska M., Pozainstancyjne środki ochrony prawnej, Warszawa 2013.

Sands P., Global Governance and the International Judiciary: Choosing Our Judges, "Contemporary Legal Problems" 2003, Vol. 56(1), DOI: https://doi.org/10.1093/clp/56.1.481.

Statute of the International Court of Justice, 26 June 1945, 59 Stat. 1055, 33 U.N.T.S. 933.

Statute of the International Tribunal for the Law of the Sea (Annex VI of the United Nations Convention on the Law of the Sea).

Zawistowski D., Niezależność sądów i niezawisłość sędziów z perspektywy prawa Unii Europejskiej, „Ruch Prawniczy i Ekonomiczny” 2016, nr 2, DOI: https://doi.org/10.14746/rpeis.2016.78.2.2.

\section{STRESZCZENIE}

Niezależność i bezstronność sędziów Europejskiego Trybunału Praw Człowieka jest niezwykle istotna w kontekście autorytetu i prawidłowego funkcjonowania samego Trybunału. Celem artykułu jest przybliżenie obecnego statusu prawnego sędziów ETPC. Szczególnej analizie zostały poddane wymogi sprawowania urzędu, procedura wyboru oraz gwarancje niezależności i bezstronności sędziów (przywileje i immunitety).

Słowa kluczowe: Europejski Trybunał Praw Człowieka; sędzia; niezależność; procedura wyboru 